\title{
The Industrial Soundscape between Fiction and Documentary Film in Italy's Long 1960s
}

\author{
ALESSANDRO CECCHI \\ University of Pisa \\ alessandro.cecchi@unipi.it
}

\begin{abstract}
During the long 1960s, which includes the culminating phase of the "economic miracle" and the beginning of the protest movement in 1968, the industrial imagination took forceful hold of the collective mind of the Italian people. While corporate films adopted the rhetoric of industrial progress, feature films offered a negative view of industrialization and underlined its problematic aspects: the exploitation of the working class, class struggle, alienation, pollution, the role of criminal enterprise. In both cases music and sound profoundly influenced the representation of the industrial contexts. Corporate films had a tendency to extol the virtues of labor and industrial production and used music extensively to this end. The wide circulation of these films in this period encouraged a critical approach to industrial contexts from feature film directors: in their films music and sound offered critical readings during the industrial sequences: they posed questions, encouraged ironic or tragic reflection, or gave the sequences grotesque or sinister overtones. This article analyzes film music and sound options in feature films against a backdrop of corporate film communication in order to trace the history of industrial imagination in Italian cinema.
\end{abstract}

Keywords: Italian film music composers; Italian auteur film; corporate film; 1960s

$\mathrm{T}$ The status of music in the cinematic representation of industrial production and working environments has been ambiguous since the beginning of sound film. Industrial subjects traditionally either entailed music being suppressed in favor of industrial sound or called for the intrusive presence of some of the most intriguing experimental film music of the time. If the latter, the music substituted, whether by wholly replacing or subsuming them within the texture, the sounds of industrial processes themselves. In Italy, this ambiguity became extremely acute as a result of two concomitant aspects of the rapid industrialization that characterized the post-war period. ${ }^{1}$ First, the exponential rise in production and the pervasive circulation of films

1 See Paul Ginsborg, A History of Contemporary Italy: Society and Politics 19431988 (London: Penguin Books, 1990), 210-53. involved in corporate communication and brand promotion-including prestige films sponsored by Edison, ENI, FIAT, Innocenti, Italsider, and Olivettiencouraged musical experimentation and a remarkable audiovisual ingenuity. ${ }^{2}$ Second, the significant, albeit limited, presence of fiction films referring to and critically reflecting on industry brought to light—mostly but not exclusively from a Marxist orientation - the "dark side" of industrialization and corporate ideology. In this effort, music was a

2 See Alessandro Cecchi, "Creative Titles: Audiovisual Experimentation and Self-reflexivity in Italian Industrial Films of the Economic Miracle and After," Music, Sound, and the Moving Image 8, no. 2 (2014), 179-94. On Italian industrial film in general, see Elena Mosconi, "Il film industriale," Comunicazioni Sociali 13, nos. 1-2 (1991), 61-90; Elena Mosconi and Luigi Boledi, "Il film industriale," in Un secolo di cinema a Milano, ed. R. De Berti (Milan: Il Castoro, 1996), 295-311; Anna Maria Falchero, "Cinema e industria: I documentari industriali,” Storia-Politica-Società 41, nos. 3-4 (2008), 129-42; Giulio Latini, L'energia e lo sguardo: Il cinema dell'Eni e $i$ documentari di Gilbert Bovay (Rome: Donzelli, 2011). 
privileged vehicle for the communication of their critical stance.

In both cases, filmmakers and musicians turned to a wide range of options: the traditional symphonic orchestra, experimental music, jazz, electronic, and recorded industrial sound (including Foley) used as "tape" music. They also explored combinations, allusions, and hybridizations. Investigating this sound-music continuum requires one from time to time to focus either on musical structures, topics, and compositional choices or on their concrete sonic deployment within an overall sound organization (aware of their presence in a film soundtrack as the result of post-production processes including rerecording and mixing). Moreover, cinema has to be considered in its media and production context, including specific film genres and their forms of circulation. In dealing with the industrial soundscape as film soundscape, therefore, the following discussion will address the role of music and sound as aspects of the overall rhetorical strategy used in Italian fiction films. These will be considered against the backdrop of the pervasive presence of industrial films in the years of the "economic miracle" (1958-63) as well as the subsequent period of crisis characterized by protest movements and political struggle (labeled the "era of collective action"). ${ }^{3}$

\section{Intertextual Exchanges between Fiction and Documentary}

During the years of the economic miracle, many facets of industrial production quickly and forcefully took hold in the collective imagination of the Italian people. Cinema productions responded to this in two fundamentally different manners: on the one hand, corporate films took on the rhetoric of industrial progress and opted-not without exceptions-for a positive and hopeful representation of corporations and their activities; on the other hand, feature films reacted against this tendency by adopting a critical attitude towards industrialization in order to highlight its most problematic aspects (the exploitation of the working class, the resulting strikes and protests, class conflict, the problem of social and individual alienation, health problems of the workers, the consequences of pollution, the relations between industrial and criminal enterprises, and so forth). The considerable use of music as a significant part of the cinematic communication brought these two strands

3 See Ginsborg, A History of Contemporary Italy, 298-347. together. In industrial films the synchronization of music and industrial processes extolled the virtues of labor and industrial production. Fictions displayed a more nuanced approach. Filming industrial processes in the context of narrative provided filmmakers with the opportunity either of including industrial sounds as a desirable form of discontinuity, thereby dispensing with the presence of music, or letting film music shape images of the industrial process itself. These possibilities produced subtle critical readings in which the music can be heard as posing questions, establishing an ironic distance, or imparting comic, tragic, grotesque, or sinister overtones. In all these cases, film music helps to provide rhetorical strategies, and also contributes to the definition of a film's genre.

An early case featuring elements specifically suited to industrial films within the context of a fiction is Roberto Rossellini's Europe '51 (Europa '51, 1952). The film devotes a number of sequences to the working environment where Irene (Ingrid Bergman), the wife of a rich industrialist, seeks refuge following the death of her child Michele due to complications from his suicide attempt. In search of atonement, Irene decides to help the poor and share their pain. For a while she takes the place of a female worker in a printing works. This allows her to experience factory work firsthand. It soon becomes apparent that the industrial environment-and particularly its soundscape, as evident in the sequences featuring neither music nor dialogue-plunges her into a state of even greater anguish (Figure 1).

One evening Irene returns home late from work and refuses to join her upper-class family as they go to the opera. She prefers to go out alone and seeks distraction in a cinema as working-class entertainment. Between the end of Irene's altercation with her husband George (Alexander Knox), who has insulted her for her inexplicable behavior, and the moment in which she enters the cinema we hear Renzo Rossellini's music. Written in a pathetic opera style combining Wagnerian and verismo inflections, the cue is clearly meant to convey her psychological state and inner drama. Posters near the movie theater advertise the comedy film Totò terzo uomo (dir. Mario Mattoli, 1951), a parody of Carol Reed's The Third Man. Once inside, Irene starts watching one of the newsreel documentaries which in those years were standard fare before the feature presentation proper. Before we see any of its images, we hear the offscreen soundtrack. The music stands in sharp contrast to the previous cue. It is redolent of the music for industrial films of those years, conceived so as to be 


\section{Figure 1: Europe '51 (dir. Roberto Rossellini, 1952): Irene (Ingrid Bergman) at work}

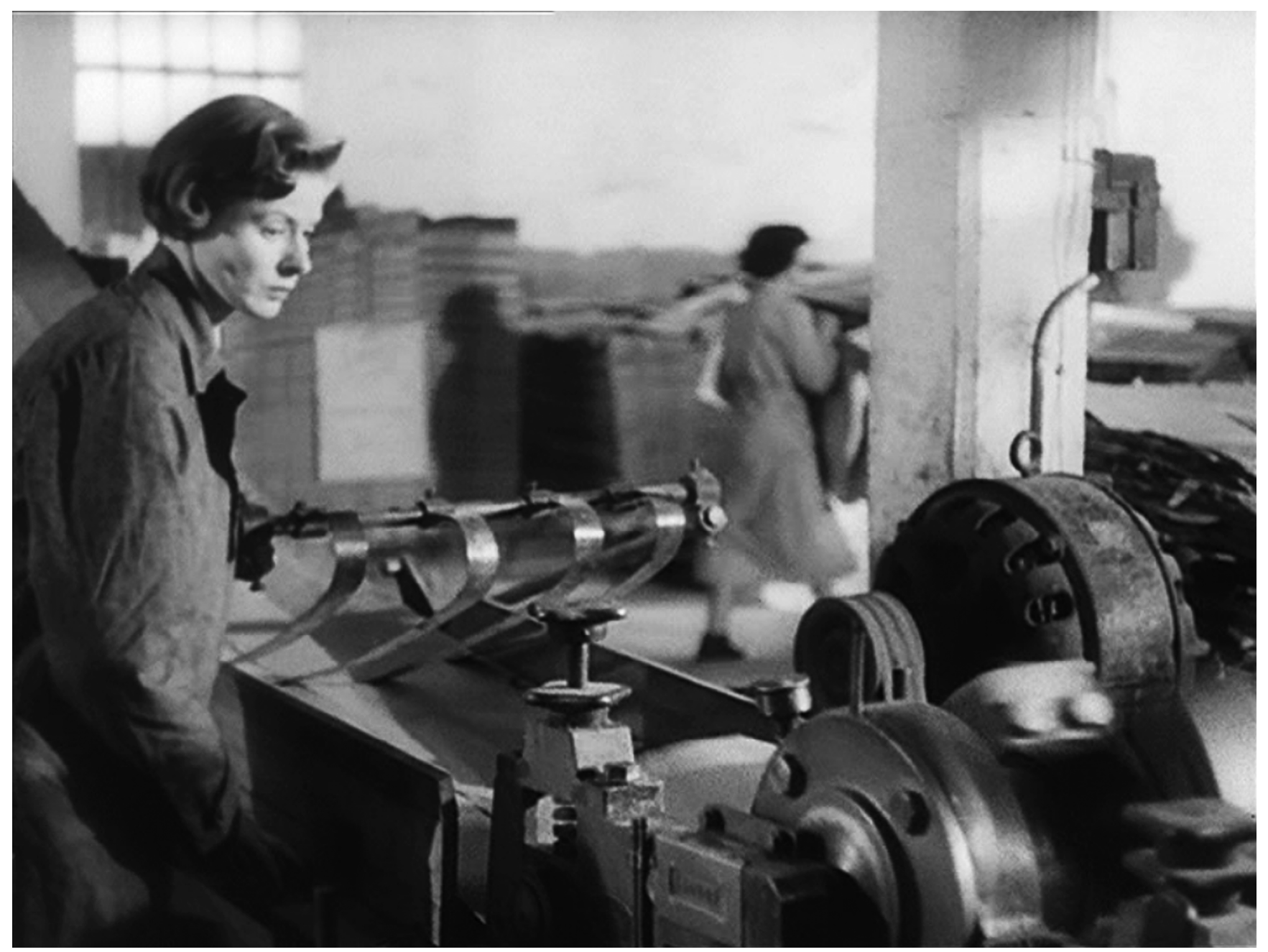

synchronized with the images and establish mimetic correspondences between motivic motions and mechanical movements, instrumental timbres and the sound of industrial processes. The voice-over describes the sacrifices made by the inhabitants of small villages leaving their homes to allow for the flooding of a vast basin after the construction of a dam. The tone is sad and poignant. But it is the full orchestral sound accompanying the waterfalls, and more precisely the whirlpool produced by the opening of the dam, that becomes the new soundtrack of Irene's anguish (Figure 2).

Irene draws from the Jewish-Christian tradition and borrows verses from Genesis in the Old Testament. In contrast to the progressive view, she conceives of work in deeply religious terms as a consequence of original sin: that is, a condemnation to daily and inescapable pain in exchange for eternal redemption. The sight and sound of the rotary press in the printing works and the whirlpool in the newsreel documentary lead her to express her personal vision in the dialogue with her cousin Andrea (Ettore Giannini) which follows immediately thereafter: "I had to see it, this work, I had to feel it! I am terrified, believe me. I understand: it truly is a condemnation, a frightful condemnation." 4 She responds to the socialist position expressed by Andrea (who is a journalist) by repeating: "I have seen them: they are like so many slaves in chains." Her solution is strongly inspired by her religious beliefs: "But if they were all able to understand that work is not only a duty but a condemnation-'You will work hard for your food'-then we would probably all feel closer, all the same, all humiliated in the same way, and we would seek salvation together." It is clear that Irene, whose

4 All translations into English are the author's. 


\section{Figure 2: Europe'51 (dir. Roberto Rossellini, 1952): a) Frames of the whirlpool in the industrial film; b) Close-up of Irene (Ingrid Bergman) watching the film}

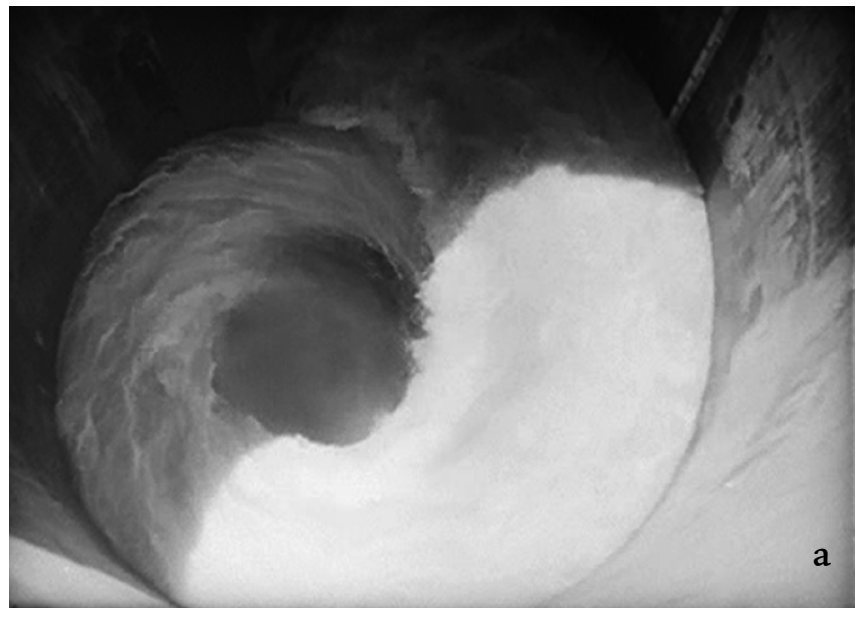

character is vaguely modeled after Simone Weil, ${ }^{5}$ sees the working process through a tragic lens, thus offering an against-the-grain reading of industrial ideology and rhetoric. But her family interprets her position as the symptom of an inexplicable neurosis, and she ends up in a psychiatric hospital.

In the late 1950s through the 1960s, intertextual exchanges between fiction and documentary films became frequent in both directions. The more eclectic character of industrial films entailed that fiction films could be evoked freely when relevant to the communication strategy of a given sequence. Such is the case of CNRN (Comitato Nazionale per le Ricerche Nucleari) industrial film production Ispra 1 (dir. Gian Luigi Lomazzi, 1959). Ispra 1 was one of the first Italian films to make extensive use of musique concrète and electronically produced sound (created, as on several other occasions, by Luciano Berio at RAI's Studio di Fonologia in Milan). In a sequence about nuclear energy research, the voice-over describes the operator at the glovebox in the laboratory as a "sci-fi film character," 6 while electronic sonorities create a soundscape comparable to that composed by Louis and Bebe Barron for Forbidden Planet (dir. Fred M. Wilcox, 1956). ${ }^{7}$

5 See Lisabeth During, "Saints, Scandals, and the Politics of Love: Simone Weil, Ingrid Bergman, Roberto Rossellini," Substance 45, no. 3 (2016), 16 32; Elena Dagrada, Le varianti trasparenti: I film con Ingrid Bergman di Roberto Rossellini (Milan: LED, 2005)

6 See Alessandro Cecchi, "Topoi of Technology in Italian 'Experimental' Industrial Film (1959-1973)," in Proceedings of the International Conference on Music Semiotics in Memory of Raymond Monelle (University of Edinburgh, 26-28 October 2012), ed. N. Panos et al. (Edinburgh: IPMDS, 2013), 394-403, http://sites.ace.ed.ac.uk/edmusemiotics/proceedings.

7 See James Wierzbicki, Louis and Bebe Barron's Forbidden Planet: A Film Score Guide (Lanham, MD: Scarecrow Press, 2005). See also William R. Rosar,

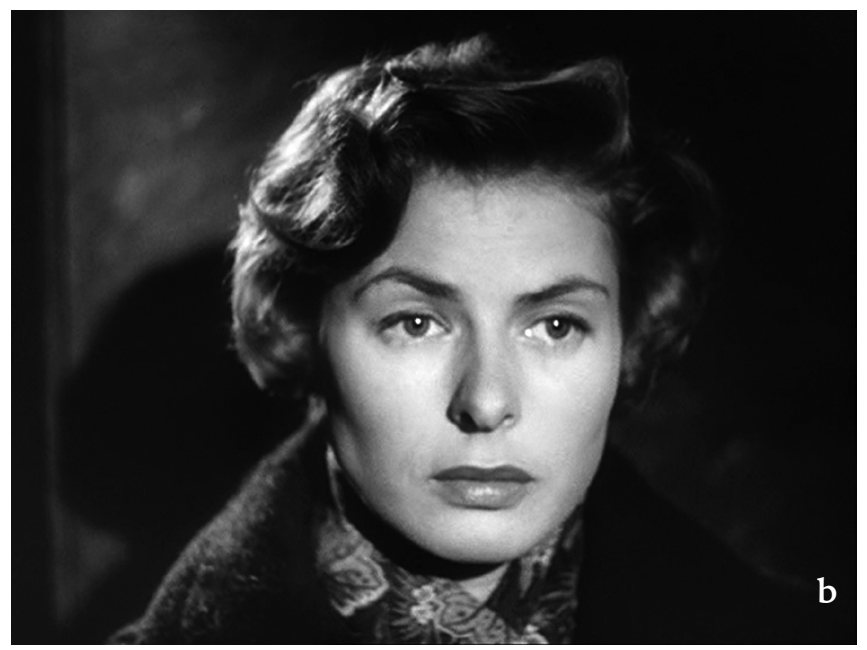

Later in the 1960s, the second episode (Il viaggio ["the journey"]) of the ENI-sponsored feature-length industrial film La via del petrolio ("the path of oil"), directed by Bernardo Bertolucci in 1965-66 and televised by RAI in early 1967, with music by Egisto Macchi, would indulge in visual quotations from fiction films, including Michelangelo Antonioni's Red Desert (Il deserto rosso, 1964). The ships passing through the Suez Canal clearly allude to the image of the huge ship silently appearing in the fog of the Ravenna harbor in Red Desert. Here the reality of cinema takes over the documented reality of the industrial environment, showing that the experience of industry can only exist in a continuum with the cinematic representation. No less interestingly, in the third episode of the same documentary (Attraverso l'Europa ["across Europe"]) Argentinean poet and screenwriter Mario Trejo, who plays himself as a journalist, also comments on the industrial landscape by evoking the poetic visions of the recent film: "It is like being in Antonioni's Red Desert." Mario is speaking to an employee who is in charge at the ENI pipeline and continues by asking: "Are people here as neurotic as the ones in the film?" The worker answers: "No, obviously." In putting aside with a smile this hypothesis as if it were a joke, both the poetjournalist and the workman reveal their awareness of the main difference between documentaries and fictions. Bertolucci makes this explicit: the difference does not primarily concern the issue of "realism" but

"Music for Martians: Schillinger's Two Tonics and Harmony of Fourths in Leith Steven's Score for War of the Worlds (1953)," Journal of Film Music 1, no. 4 (2006) ("Leith Amadeus Stevens: A Festschrift"), 395-438. 
rather that of film genre, which implies a different rhetorical construction. Fictions obviously exaggerate negative feelings so as to affect the spectators and get them involved in the plot or in the psychology of the main characters.

Red Desert includes quotations in the opposite direction, the most striking being the dialogue scene between the protagonist Giuliana (Monica Vitti) and a workman shown in the guise of an acrobat on the trellis framework. The man explains to her, as in an industrial film, the function of all the surrounding trellises-forming an antenna so as to capture the sound of the stars - while loud industrial sound provides the unpleasant sonic background. This setting is a homage to the first episode of the unreleased yet well-known-at least in restricted intellectual circles-film by Joris Ivens, L'Italia non è un paese povero ["Italy is not a poor country"] (1959-60). ${ }^{8}$ This failed PROA (Produttori Associati) production was commissioned by ENI's President Enrico Mattei. The film was later completely re-edited by RAI in order to conform to the official stance of the Italian government and broadcast in three summer nights in 1960 as "fragments from a film by Joris Ivens" along the line of Ivens's three original episodes. ${ }^{9}$ Both versions of the film include music by Gino Marinuzzi Jr., who also provided the film with some electronic sound effects particularly prominent in an extended dream sequence, with explicit cross-references to both sci-fi and industrial film sound environments. In the same year, the winner of the Venice Documentary Film Festival was Elea classe 9000 (dir. Nelo Risi, 1960), an Olivetti corporate image film featuring electronic and instrumental music by Berio. ${ }^{10}$ The extensive use of electronic music was initially within the purview of industrial films in Italy. Only later did electronic music begin to appear in fiction films.

Red Desert is in this respect a pivotal work. Antonioni relied on his own experience as an industrial film director. ${ }^{11} \mathrm{He}$ capitalized on the industrial soundscape and at the same time

8 See Mario Verdone, "Note: L'Italia non è un paese povero", Bianco e Nero 21, no. 7 (1960), 87-90.

9 See Alessandro Cecchi and Maurizio Corbella, "Experimentation, Documentation, Censorship: A Joris Ivens's Industrial Film and the Italian National Broadcasting Television" (paper delivered at Music and Media 4th IMS Study Group Meeting, Turin, June 28-29, 2012).

10 See Adriano Bellotto, La memoria del futuro: Film d'arte, film e video industriali Olivetti 1949-1992 (Rome: Fondazione Adriano Olivetti, 1994), 135-6, 166. See also Cecchi, "Creative Titles", 185-7. In those years Olivetti's sponsorship involved not only cinema but art in general, including architecture. The Venice showroom in St. Mark's Square, designed by Carlo Scarpa near the end of the 1950s, is perhaps the most striking example. 11 I am referring to Sette canne, un vestito ("Seven reeds, one suit") (1949), a SNIA-sponsored film on viscose production directed by Antonioni, with orchestral music by Giovanni Fusco. radicalized it via the pervasive use of direct sound and extended fragments of Vittorio Gelmetti's electronic music. Giovanni Fusco was also involved as composer. His vocal music, scored for the voice of his daughter Cecilia, evokes nature in terms of otherness, and in the films represents the dimension of the imagination..$^{12}$ Antonioni also intentionally aimed at subverting the rules of industrial film, taking a critical stance towards its traditional forms of audiovisual presentation. The celebrated outof-focus shots of the factory seen in the opening credits-famously rhyming with the superimposition of Gelmetti's electronic music over industrial noise, to which Cecilia Fusco's voice is added soon afterwould be unthinkable in a documentary film as the blurred image, which disquiets the spectator while beautifying the title sequence, would contradict the task of documenting the factory (Figure 3). Yet this critique of the industrial film is disconnected from any attempt to mobilize people towards political action. What Antonioni seeks to represent is the misery of the upper classes as an irreversible condition. There is no way out, unless it is an imaginary one, of the world they live in and have talked themselves into.

\section{Figure 3: Red Desert (dir. Michelangelo Antonioni, 1964): an example of blurred factory shot in the opening titles}

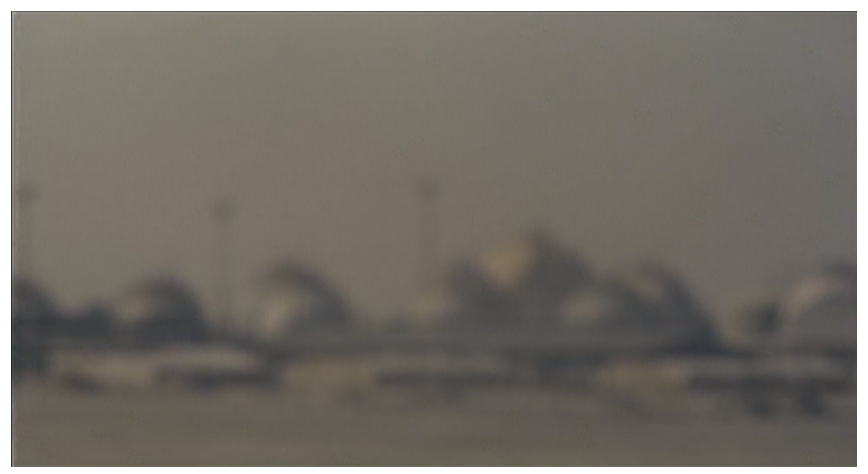

Like Rossellini, Antonioni chooses to focus on the confused psychological attitude of the female protagonist Giuliana, the wife of a corporate leader. What vaguely emerges from the storyline is that she has attempted suicide. Her neurosis is clearly aligned

12 See Roberto Calabretto, Lo schermo sonoro: La musica per film (Venice: Marsilio, 2010), 218-20; Maurizio Corbella, "Sperimentazione elettroacustica e cinema d'autore in Italia negli anni Sessanta: Due casi di studio," Comunicazioni Sociali 2011, no. 1 (2011), 93-101; Roberto Calabretto, Antonioni e la musica (Venice: Marsilio, 2012), 137-62. 


\section{Figure 4: Red Desert (dir. Michelangelo Antonioni, 1964): a) close-up of Giuliana (Monica Vitti) near the end of the film; b) close-up of her hair}

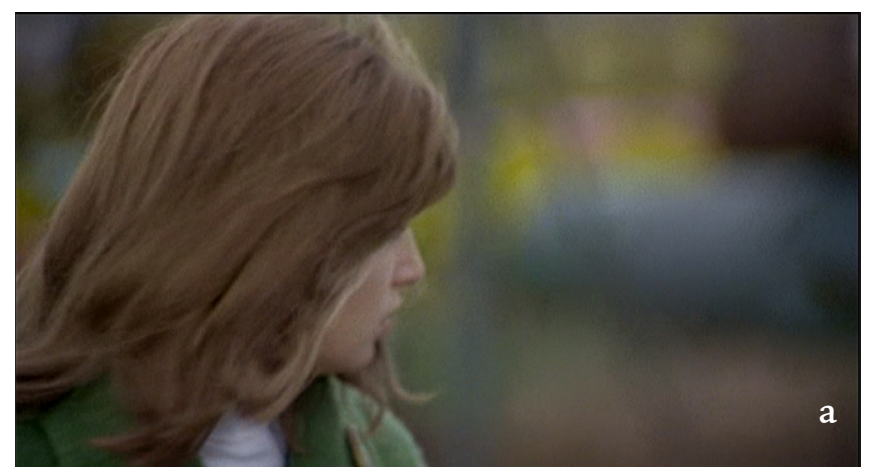

with both the industrial landscape and the electronic soundscape. Near the beginning of the film, she visits her husband in the factory with her child. On the way, she comes across two agitators with loudspeakers inciting the workers to strike. Unlike these men and Giuliana, the other workers outside of the factory are out of focus. Antonioni adopts blurring as an element in the construction of many of the sequences set in and around the industrial plant. Sound often disturbs and even prevents us from understanding the dialogue, just as the dense clouds of steam-a result of industrial production-invade the frame, thus hiding the main characters from view.

The industrial soundscape in the sequences that bookend the film portrays Giuliana both as outwardly alien and secretly bound to the industrial landscape. As she tells a foreign sailor-whom she met by chance toward the end of the film around the mysterious plague-infected ship-she has to think that all that happens to her is just her life. Which means she has to accept it, including both her inexplicable neurosis and the factory, with all its undeniably disquieting soundscape and the pollution it produces: the yellow smoke or the "poison" that her child believes would kill birds flying by. But the birds-she says-have learned about it by now and avoid flying through it. The film ends with a close-up of Giuliana (Figure 4). The electronic sound overlapping with the noise coming from the factory indicates that her neurosis will not go away. She simply has to learn how to avoid being killed by it.

Even in this case, neurosis goes hand in hand with the industrial landscape, while the soundscape, augmented by the music, both endorses and aestheticizes the suffering of the protagonist. The industrial film is part of the play, but the rhetorical

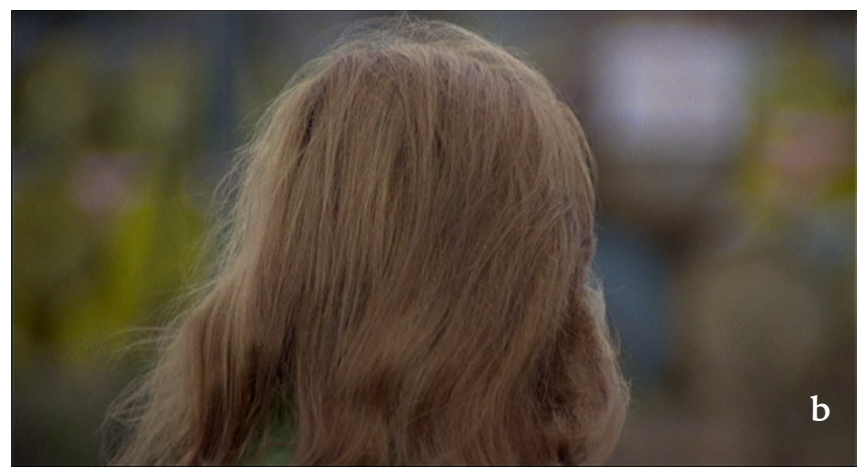

construction of Antonioni's film is irreducibly distant from it.

\section{Negotiating the Soundscape among Film Genres}

In Alberto Lattuada's Mafioso (1962) music is an effective means of establishing rhetorical strategies. The film is characterized by a unique combination of film genres including industrial film, Mafia and gangster movies, and comedy Italian style. Right at the beginning, it showcases the working process of the assembly line at the Innocenti automobile factory in Lambrate, a district of Milan. This serves as an occasion to introduce the problem of possible connections between industrial corporations in northern Italy and organized crime-here the Sicilian Mafia. The latter is no longer portrayed as a picturesque, typically rural phenomenon. It has evolved into a criminal corporation with ramifications both at national and international level. Albeit portrayed in a surreal manner, and as a fictional device, organized crime is one aspect of the dark side of industrialization to which corporate films obviously avoided alluding.

Most relevant to the present discussion is the encapsulation of a Mafia film within the context of an industrial film. The title sequence is neither quotation nor parody, but industrial film proper in terms of both shooting technique and audiovisual construction. It is notable that this sequence depicts exactly the same working processes-often through the same camera setups - as Noi continuiamo... ("we shall carry on") (dir. Mario Damicelli, 1968), an industrial film produced by carmaker Innocenti in which the steps of 


\section{Example 1: Mafioso (dir. Alberto Lattuada, 1962): a) transcription of Piero Piccioni's waltz theme (beginning) as heard in the film's opening titles; b) comparison with the beginning of 'Libiamo', in Giuseppe Verdi's La traviata}

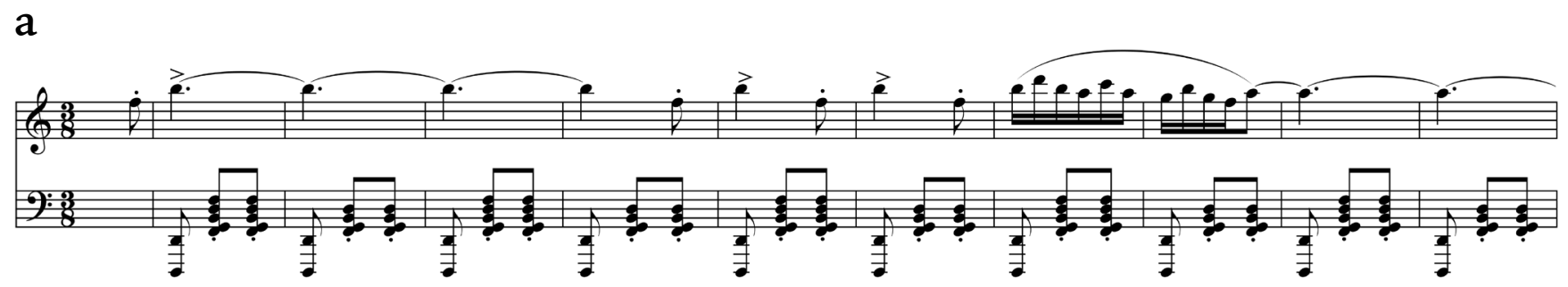

b

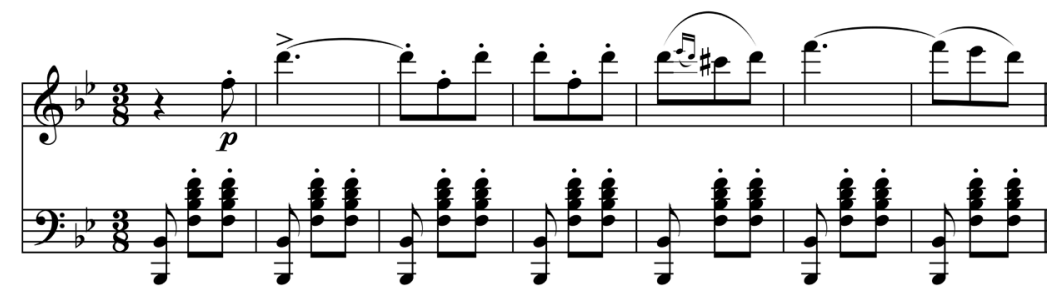

the setup of an automobile along the same assembly line are accompanied by Egisto Macchi's electronic and tape music (and feature sync points that verge on the edge of Mickey Mousing). ${ }^{13}$

In Mafioso the Innocenti logo serves the purpose of validating reality, as does the industrial sound (as yet uninflected by music). The first credit, carrying the producer's name, is also still in line with the rhetoric of the industrial film. But the second credit, the name of iconic film star Alberto Sordi, foreshadows his role as that of the protagonist Antonio ("Nino") Badalamenti and thus gives away the true nature of the film. The third credit confirms the identification between this actor and the substantivized adjectivein capital letters-selected as the film's title. The upbeat of the music by Piero Piccioni appears immediately before the title, so that a sync point obtains between the film's title and the main beat of the waltz. The opening interval is a tritone (F-B) and is repeated three times, just like the major sixth of the famous 'Libiamo' in the first act of $L a$ traviata (which seems to have been its model). The tritone is central to the Lydian scale on which the continuation of the theme insists (Example 1). The synchronization between the topos of the tritone as diabolus in musica ${ }^{14}$ and the word "Mafioso" could not

13 On Macchi's film music, see Marco Cosci's article in the present issue. 14 On the use of the tritone in film music, see Philip Tagg, "Tritonal crime and 'music as music'," in Norme con ironie: Scritti per $i$ settant'anni di Ennio Morricone, ed. S. Miceli (Milan: Suvini Zerboni, 1998), 273-312, accessed be more obvious. The allusion to La traviata could stand for the emancipated European city-here Milan-and its secular, even frivolous life, as opposed to rural and archaic Sicily. ${ }^{15}$ On the other hand, the Lydian inflection could be heard as vaguely Oriental (albeit rarely, Sicilian songs too can betray a Lydian character).

The waltz rhythm is underlined by heavy accents in the low brass instruments. These are also free to move against the ternary rhythm of the waltz, producing hemiola effects for the superimposition of binary rhythm. Jazz inflections are clearly present in the brass section. The choice of instruments is in line with the industrial setting and the musical tradition of corporate films dealing with heavy industry. Trombones can be used to imitate the noises of the working environment, particularly through the use of glissandi (as is indeed the case in Piccioni's score). Yet the waltz is too attractive and musically distinctive to fit properly into an industrial film, and the subterranean reference to Italian opera is more suitable to the narrative strategies of a fiction. ${ }^{16}$

March 2017, http://tagg.org/articles/xpdfs/morric70.pdf; Janet K. Halfyard, "Mischief Afoot: Supernatural Horror-Comedies and the Diabolus in Musica," in Music in the Horror Film: Listening to Fear, ed. N. Lerner (New York/

London: Routledge, 2010), 21-37; Joakim Tillman, "Topoi and Intertextuality: Narrative Function in Hans Zimmer's and Lisa Gerrard's Music to Gladiator," in Music in Epic Film: Listening to Spectacle, ed. S.C. Meyer (New York/London: Routledge, 2017), 59-85.

15 On the Sicilian part of the film, see Maurizio Corbella's article in the present issue.

16 See Matteo Giuggioli's article in the present issue. 


\section{Figure 5: Mafioso (dir. Alberto Lattuada, 1962): Antonio Badalamenti (Alberto Sordi) at the end of the film's opening titles}

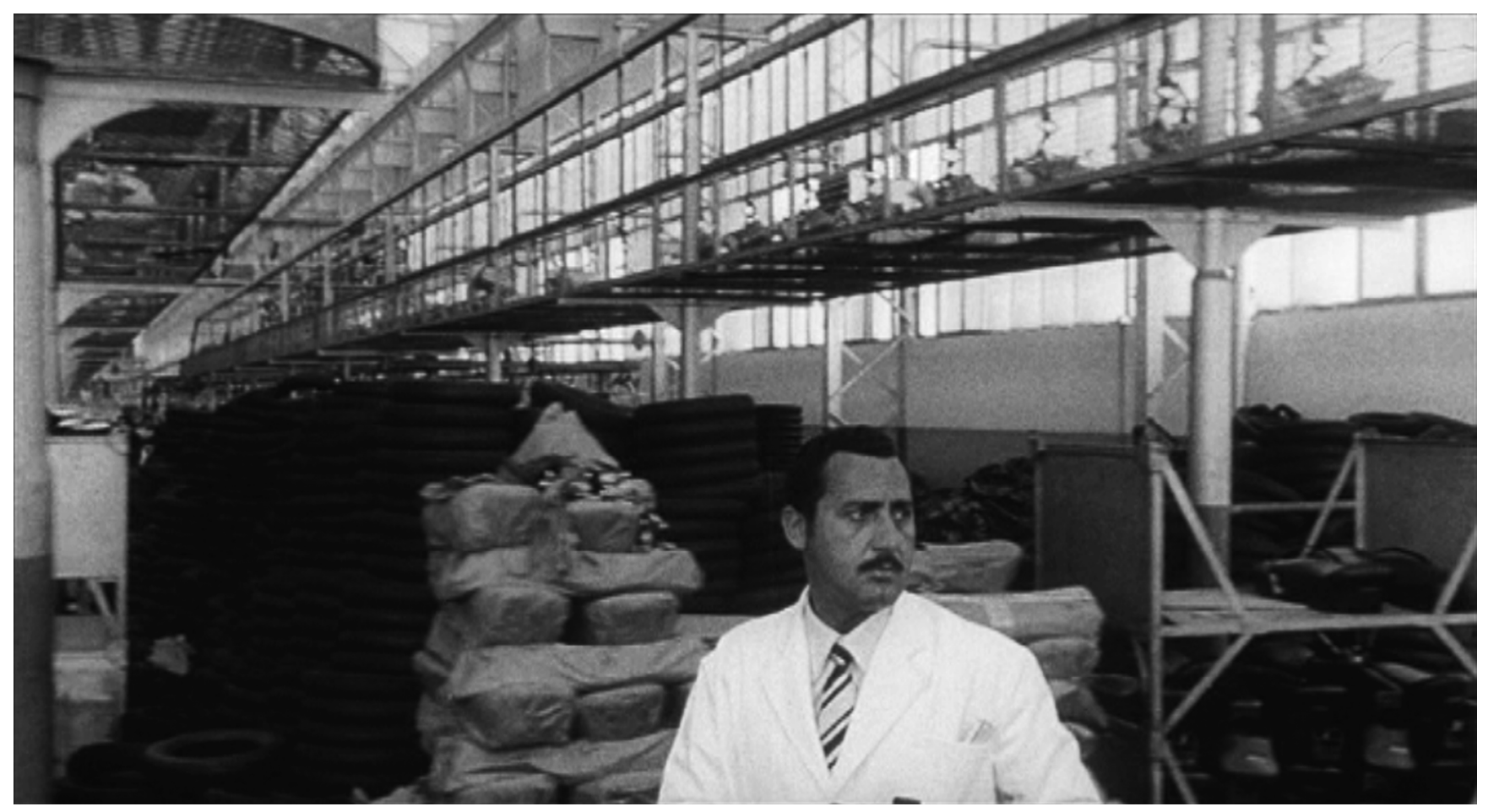

At the end of the title sequence Sordi finally appears and the camera obligingly focuses on him (Figure 5). This is the kind of framing technique that an industrial film would consciously avoid, privileging, rather, the working environment. Shooting angles are invariably chosen to best frame the work as a generalized process, rather than the predicament of an individual worker. The very moment in which the spectator recognizes Sordi-a hugely popular and highly connoted figure in Italian culture-corresponds to the emergence of a "dissonance," more precisely a dissonant cluster scored for flutes in flutter-tongue technique. ${ }^{17}$ These ascend chromatically and pierce the texture starting from a $\mathrm{C} \#$ (a black note). Albeit esoteric, the reference to early music reinforces the pictorial topos of black as the morally negative (Example 2). This is repeated three times just like the tritone at the beginning, and seems to point to the protagonist (as Sordi's affected Sicilian inflection will confirm immediately thereafter). The passage connects with the cue sheet in which Piccioni refers to the "Mafia effect."18 There, the two outer voices of the

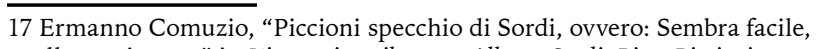
quella musica ...." in L'immagine e il suono: Alberto Sordi-Piero Piccioni. Seminario di studio e premio "Il Trefolo d'oro". Università per Stranieri di Siena, ed. S. Micheli (Siena: Il leccio, 1994), 14.

18 See Maurizio Corbella's article in the present issue (Figure 6). two-note chord motif move chromatically in contrary motion, also starting with a black note ( $\mathrm{F} \#$ in the flutes). Sordi's character as "Mafioso" is the southern "other" (black note) infiltrated in the otherwise honest, or seemingly so, northern corporation (white notes).

Yet the character he plays is nonetheless a serious, honest, effective, and also compassionate foreman. Badalamenti's task on the Innocenti assembly line is to record and decide the timing of the process. One must stress that the figure of the timekeeper in no way ever occurs in industrial films, which, in fact, systematically efface or smooth over social tensions in the working environment (mediating, for instance, between white- and blue-collar workers). The foreman was generally seen as an enemy of the working class, owing to the nature of the job: imposing time requirements to enhance production and thus acting against the workers. Yet Badalamenti is different. He is not only particularly conscientious and meticulous but he also gently reproaches a worker for working too fast and risking injury. In fact his general tendency is to slacken the pace in the interests of the workers' health. Antonio fulfills his role in an exemplary way, and it is his dependability and effectiveness that draws him to the attention of the Sicilian Mafia. 


\section{Example 2: Mafioso (dir. Alberto Lattuada, 1962): the dissonant chord motif at the end of Piero Piccioni's waltz theme as heard in the film's opening titles}

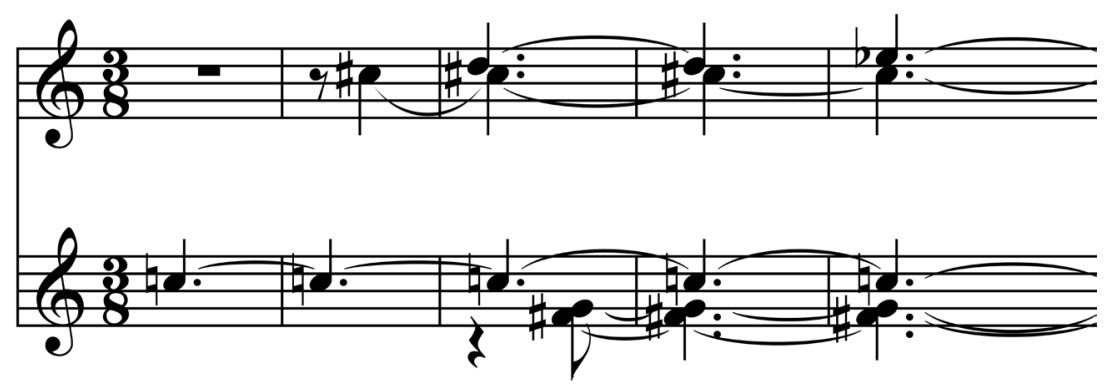

In Mafioso, the "Mafia movie" genre occupies the central part of the film, allowing one to read the outer, symmetrically opposed industrial sequences in two completely different ways. By the end we know who Badalamenti really is (even though he is not, in principle if not in fact, guilty himself). The end sequence offers the same elements as the beginning, but in reverse order, like a chiasmus. In the beginning we moved from the establishing shot of the factory and the as-yet unknown protagonist to his close-up and a close look at his visit to the office before leaving for Sicily; near the end, Badalamenti is back in Milan: he visits the same office and returns to the assembly line, walking through the factory and leaving the building while greeting the workers. This is followed by a high-angle crane shot which begins from just over his shoulders and ends when he is no longer recognizable (Figure 6). It is this very anonymity that veils the underground relations between employee, corporate leader, and criminal enterprise. The obsessive music of the beginning appears just before the end credits and has a completely different effect on the viewer. We know he is a killer against his own will and values, and we are aware of the fact that the murder will remain his secret, for he is and must in any event remain loyal to the Sicilian comrades.

One year after the release of Mafioso, director Ugo Gregoretti, financed by producer Franco Cristaldi who dared him to make a film about a "modern-day Don Quixote,"19 decided to deal with another aspect of the "dark side" of industrialization. The resulting film, Omicron (1963), also combines different film genres. It is basically a sci-fi movie and a comedy Italian style, but also contains elements of the spy film. The combination gives rise to a satire consisting of an

19 Valentina Punzo, La società italiana degli anni '60 vista dalle stelle: Omicron, un film di Ugo Gregoretti (interview with Ugo Gregoretti), 2009, accessed August 2018, https://vimeo.com/7457685. See also the interview with Gregoretti in Omicron, DVD (Dolmen Home Video, 2009). explicitly Marxist reading of capitalism and corporate industry in general. Gregoretti took the film's concept from a semi-clandestine investigation into the conditions of the working class at FIAT's factories in Turin: Inchiesta alla FIAT, by journalist Giovanni Carocci. ${ }^{20}$ Despite its roots in journalism, the story developed in terms of a sci-fi parody. One clear reference is to Invasion of the Body Snatchers (dir. Don Siegel, 1956), an allusion to the Italian title (L'invasione degli ultracorpi) residing in the name of the planet Ultra (where the alien protagonist Omicron comes from). The result is an intentionally non-credible sci-fi plot. ${ }^{21}$

The concept traces a rough equivalence between the alienation suffered by the working class as a consequence of both exploitation and consumerism and the alien Omicron, who has come to Earth to take over the body of a man chosen at random. This man happens to be worker Angelo Trabucco, played by Renato Salvatori, an employee at the fictional S.M.S. corporation. In the first sequence, an English nanny chasing the two children in her care discovers an unnaturally rigid, seemingly dead body lying in one of many huge industrial pipes found there. These props offer an opportunity to create a striking representation of the sound of the woman's voice. As she yells at the children we hear intermittent echoes moving across the empty pipes, culminating in the scream that marks the gruesome discovery of what appears to be a corpse. All along, the listening point accurately matches that of the camera, which frames the woman through the pipe (Figure 7 ). The scream paves the way for a close shot of the corpse seen from the soles of its shoes, which in turn coincides with a dense thirteenth chord in the brass-a jazz-inspired stinger that was typical in the spy films of the time.

20 Giovanni Carocci, “Inchiesta alla FIAT,” Nuovi Argomenti 31-32 (1958); Giovanni Carocci, Inchiesta alla FIAT (Florence: Tipografia Parenti, 1960). 21 See Eliot Chayt, "Revisiting Italian Post-neorealist Science-Fiction Cinema (1963-74)," Science Fiction Studies 42, no. 2 (2015), 322-38. 


\section{Figure 6: Mafioso (dir. Alberto Lattuada, 1962): crane shot of Antonio Badalamenti (Alberto Sordi) at the end of the film}

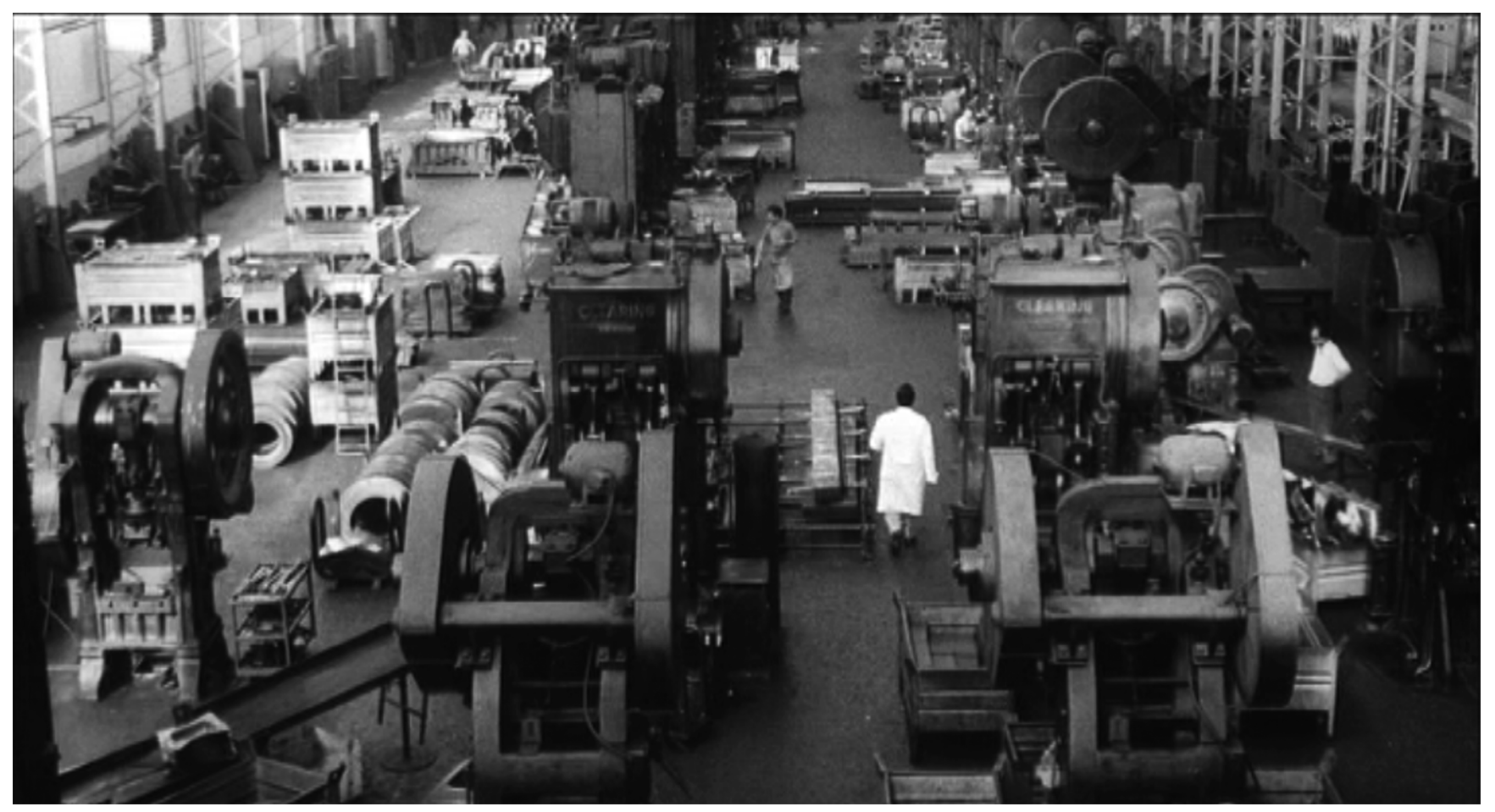

At the mortuary, and just before the autopsy, the corpse unexpectedly starts moving in a grotesque way, almost as if it were a comic routine, with the doctors standing around it. Gradually, the body seems to reacquire its vital functions, even if its strange behavior and abilities come across as less than human. The alien has been sent to Earth with the task of learning more about human behavior in order to conquer the planet. Omicron is learning to inhabit Trabucco's body and govern its actions while psychologists, medical doctors, and scientists, as well as economists, including an emissary of Trabucco's company, try to understand this inexplicable phenomenon. A number of sequences consist of tests performed on Omicron/Trabucco. Most test sequences involve electronic sonorities - a typical sonic marker of both sci-fi films and industrial films featuring scientific experiments.

The idea of cameras in the working environmentin particular hidden cameras-is an element not originally found in Carocci's investigation. ${ }^{22}$ The device of the hidden cameras is pivotal to the

22 Carocci did discover and divulge the potentially explosive news that FIAT illegally used a secret police service to monitor the workers. Gregoretti made use of this in the film. introduction of discontinuity in the film, as shots taken from these cameras are frequently used to illustrate what happens. They also account for the extensive use of jazz orchestra music recalling Monty Norman's score for Dr. No (dir. Terence Young, 1962). Piero Umiliani's cool jazz style with bebop inflections straightforwardly evokes one spy movie topos to suggest that the workmen are being spied on by the company (Example 3). This music is invariably present in the sequences that depict the screening of images shot by the spy cameras or representing the corporation as a whole. This occurs as early as the title sequence, where we see aerial shots of Turin, also including the Lingotto FIAT plant (S.M.S. is clearly a stand-in for FIAT, just as Turin is lightly disguised as Subalpia, meaning "south of the Alps"). ${ }^{23}$

The film's social and political dimensions are introduced more clearly when Omicron/Trabucco, after a series of tests, is hired again by S.M.S. company. Omicron, whose observations about the earthmen and conversations with the aliens are in

23 Gregoretti did not receive permission to shoot his film at FIAT plants, which he had considered. Instead, the film used the Nuovo Pignone Eni plants in Florence. In Gregoretti's words, Eni seized the chance to show the democratic face of corporate industry. Interview with Ugo Gregoretti, in Omicron, DVD (Dolmen Home Video, 2009). 


\section{Figure 7: Omicron (dir. Ugo Gregoretti, 1963): the nanny's discovery of the corpse}

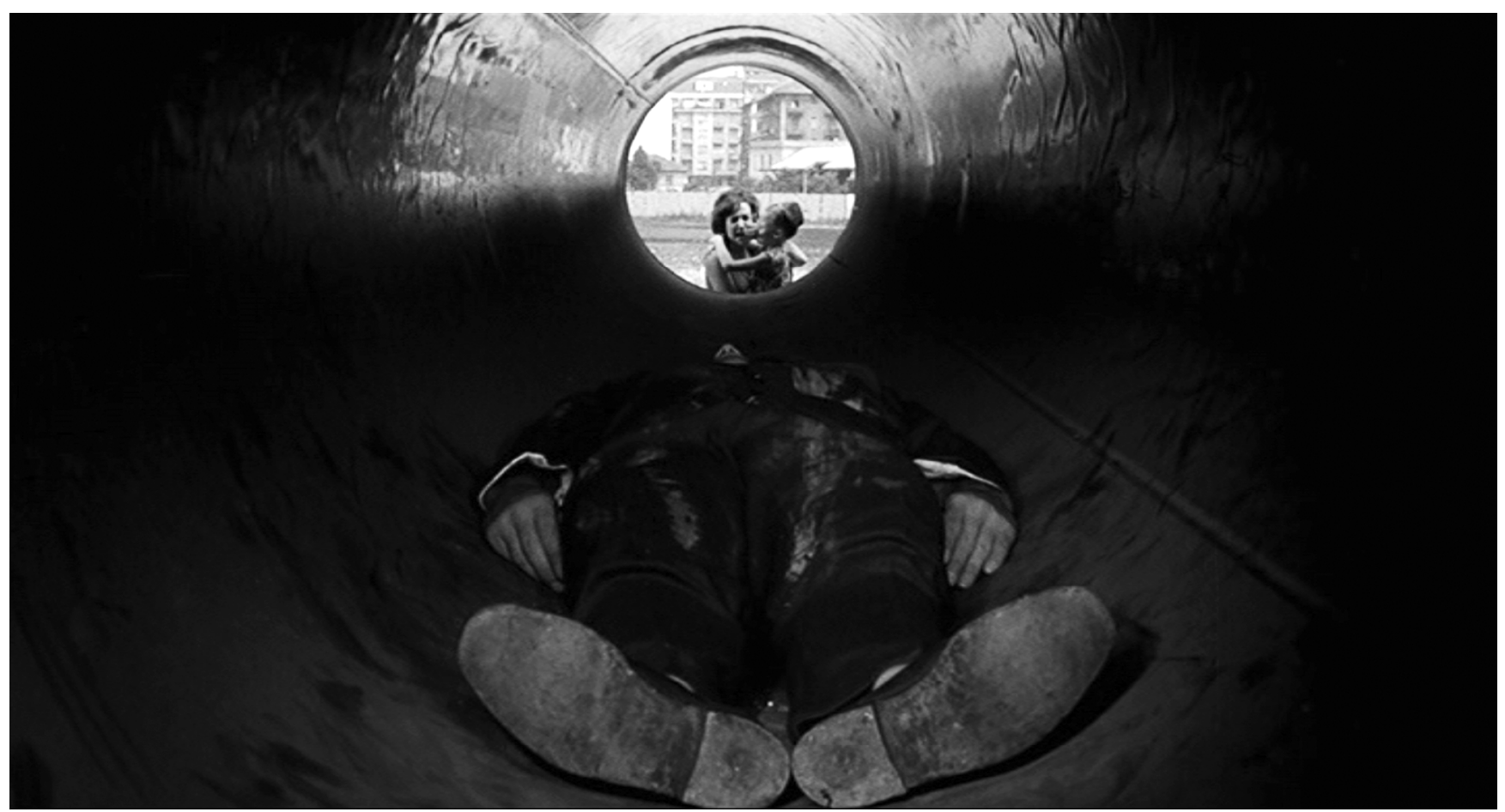

Example 3: Omicron (dir. Ugo Gregoretti, 1963): transcription of Piero Umiliani's jazz theme as heard in the film's opening titles

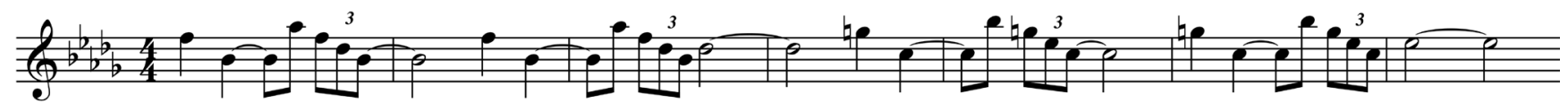

voice-over, has gradually learned to use his host body. Once sitting at his workstation, the "embodied cognition"-as we would say today-of the workman Trabucco dictates the movements enhanced by the alien presence or, more critically, by Trabucco's reduced consciousness. This results in a working performance of super-human rapidity and strength, to the extent that the S.M.S. emissary decides to exploit the circumstance in order to enhance production and force the other workers to conform to Omicron/ Trabucco's impressive stats. ${ }^{24}$ Visually, the working

24 As a side note, the film suggests a continuity and affinity between the limited coordination required to combine simple building blocks on a table - an educational game for children - and working at the assembly line, which requires a few simple and recurring movements to rapidly produce a single piece, with no overview of the project in which the piece fulfills its specific function. In Gregoretti's Marxist view, the assembly line reduces the single worker, who does not need any specialization, to an interchangeable piece. It is exactly while seeing Trabucco repeating with no rest the same action on a table with no sign of impatience that the chief proposes to test him as a workman. In the moment he envisages the new test, a loud and persistent electronic frequency is heard. test sequence represents "Omicron's irrepressible fastmotion dance of ultimate mechanization, which is an order of magnitude more callisthenic than Charlie Chaplin's lithe ballet in Modern Times." ${ }^{25}$ The subject is the production of gyroscopes, and Omicron/Trabucco produces sixty pieces per minute at the power press (six times the usual pace of the other workers). ${ }^{26}$

The sequence is accompanied by the alternation of two different patterns: a rapid four-beat rhythm the sound of which resembles that of the motion of a train-a percussion-like timbre obtained by combining the sound of different instruments, including the piano-and a random collection of intervals in the lowest register of the piano such as one hears in

25 Dennis Rothermel, "Workerist Film Humour," in Marx at the Movies: Revisiting History, Theory and Practice, ed. E. Mazierska and L. Kristensen (Basingstoke/New York: Palgrave Macmillan, 2014), 123-46 (144). 26 Fast motion is a marker of comic films and hence avoided in most ostensibly "serious" film genres, including industrial films. The latter often instead resorted to slow motion. 


\section{Figure 8: Omicron (dir. Ugo Gregoretti, 1963): Omicron/Trabucco (Renato Salvatori) at work}

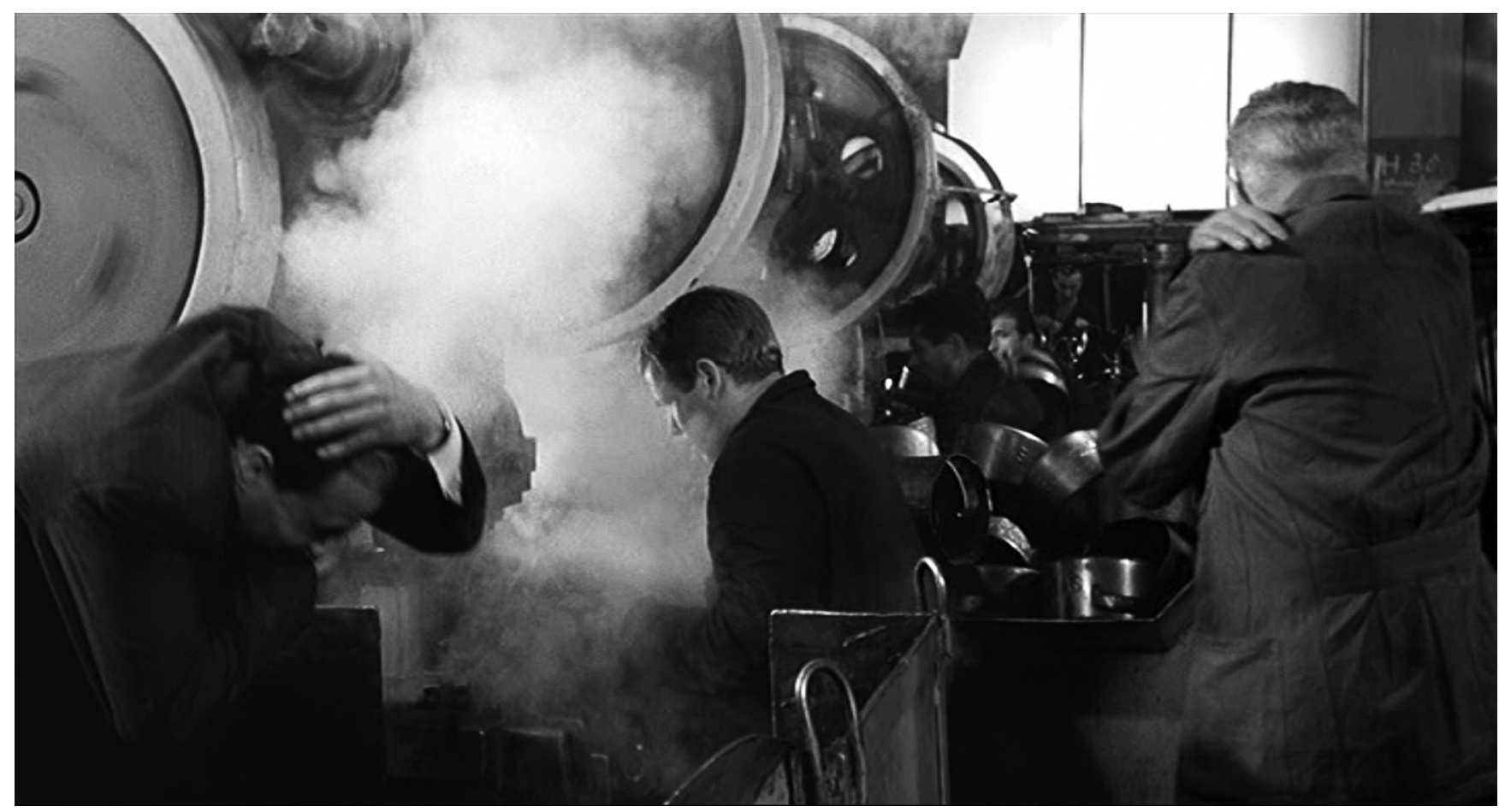

action and particularly chase sequences of a spy film. The former pattern is used when the alien worker is framed, and is perfectly in line with the sound of industrial films (which also rely on Futurist music for machines). The latter is used when the camera frames the stunned spectators of Omicron/Trabucco's super-performance. The other workers are alarmed and worried, while the foreman and the timekeeper exult about the astonishing results. No sooner has the power press crashed, emitting whistles and finally exploding due to the excessive pressure (Figure 8), the supervisor gives the order to prepare another press in order to maintain the pace of production. Here the music in itself is not in the least amusing: it is the fast motion that is funny. ${ }^{27}$

Omicron/Trabucco's performance is filmed by the cameras as though important scientific tests were being carried out. It is here that the comic register is pushed to the point where the sci-fi movie parody turns into the parody of an industrial film. In the sequence that follows, researchers and corporate managers are shown screening the film of the performance in order to analyze it. It is a clear case of

27 This confirms some of the conclusions in Miguel Mera, "Is Funny Music Funny? Contexts and Case Studies of Film Music Humor," Journal of Popular Music Studies 14, no. 2 (2002), 91-113. remediation, with elements of documentary film being channeled into a fictional context. A salient comic device lies in the manager repeatedly asking the film to be slowed down. Yet even at the slowest projection speed Omicron/Trabucco's body movements are still too fast to be analyzed.

The extreme stylistic fluctuations of the film correspond to and at the same time rely on equally extreme behaviors in the music and sound effects. If the electronic frequencies are used mainly to signify an alien presence and to represent the working environment in line with the conventions of the industrial film, the spy film-inspired jazz music allows the musical background to point to the disturbing facts that had surfaced in Carocci's investigation. As a result, the working environment is portrayed as a theater of daily crimes against the working class, a political aspect which Umiliani's music greatly contributes to underlining.

\section{The Sound of Protest and the Soundscape of the Factory}

Political events in 1968-69 showed a great deal of continuity with the disturbances of the early 
1960s. Starting with the short-lived Tambroni government (March-July 1960), relying on support from the Italian Social Movement, the party that continued the legacy of fascism, Italy experienced tensions promoted by anti-fascist movements and the working class. ${ }^{28}$ In 1968 the echo of the French May uprising reinvigorated protests by both workers and students resulting in the occupation of schools, universities, and factories, sometimes followed by active experiments in collective communities mainly involving the younger generations and the exploration of ideas such as autonomy and self-management. This period also coincided with the beginning of rightwing terrorism in Italy. Bombs went off at the FIAT stand at the Milan Fair in April 1969 and in the Banca Nazionale dell'Agricoltura in Milan's Piazza Fontana (but also in Rome) in December 1969. ${ }^{29}$ In short, the post-1968 period was characterized by a violent political struggle between radicalized movements, which took up most of the 1970s.

Films engaged with factory occupations and the hopes of the working class. Such is the case of Apollon: Una fabbrica occupata ("Apollon: an occupied factory") (1969) in which Gregoretti had a prominent, though largely uncredited, role-his being one name among many others in the collettivo di lavoro (working collective) that took credit for the film. The film features free jazz improvisations by the leading Italian saxophone player Mario Schiano (soprano and alto sax) with Marcello Melis (bass) and Marco Cristofolini (drums). This musical choice establishes a meaningful connection between free jazz, a breaking-away from the constraints of capitalist society, and the social and political experimentation embodied by the occupation. Narrated by the voice-over of Gian Maria Volonté, Apollon lies midway between documentary film and fiction. The workers were called upon to re-enact the stages of their protest and occupation immediately after the facts, thus interpreting themselves. Free jazz is used in conventional moments. The music appears at predictable junctures: in the titles bookending the film and during scenes of unrest. The soundscape of the film also features protest - and particularly partisan-songs such as 'Bella ciao' so as to underline the link between the 1968 protest movement and the Italian Resistance. The juxtaposition attempts to assimilate two seemingly polar opposites: on the one hand the canzone popolare (folk song) harks back to a tradition of collective singing in order to certify the identity of anti-fascist groups and their Marxist-

28 See Ginsborg, A History of Contemporary Italy, 254-8.

29 See Ginsborg, A History of Contemporary Italy, 333-5. inspired view of social struggle, while on the other free jazz experimentation, though in itself oriented towards avant-garde "art" music, in contemporary live performances took on a role of representing the collective identity of the protest movements. Also relevant was the relationship between free jazz and African American politics, in line with the anticapitalist ideas and anti-American feelings shared by that people.

In those same years, Italian fiction films were often oases of musical experimentation. This is the case of Partner (dir. Bernardo Bertolucci, 1968) and A Quiet Place in the Country (Un tranquillo posto di campagna; dir. Elio Petri, 1968), both scored by Ennio Morricone. The film by Petri saw also the collaboration of the Gruppo d'Improvvisazione Nuova Consonanza, providing free improvisations while relying on avantgarde models. This is also true of the improvisation group Musica Elettronica Viva, involved in Zabriskie Point (dir. Michelangelo Antonioni, 1970), or of the inclusion of Richard Teitelbaum's 'In Tune' in The Seed of Man (Il seme dell'uomo; dir. Marco Ferreri, 1969). ${ }^{30}$ Moreover, Vittorio Gelmetti's avant-garde music is featured in Under the Sign of Scorpio (Sotto il segno dello scorpione; dir. Paolo and Vittorio Taviani, 1969) and Sierra Master (Sierra Maestra; dir. Ansano Giannarelli, 1969). Gelmetti's experimental music can be found in documentary films of two ideologically antithetical kinds: corporate films on the one hand and anticapitalist, Marxist documentary films by independent producers on the other. Examples of the former are the FIAT-sponsored film Appunti per l'auto di domani ("notes for the automobile of tomorrow") (dir. Massimo Mida, 1968) and the Olivetti production $L a$ macchina del tempo ("the time machine") (dir. Antonello Branca, 1969). The most significant example of the latter is the REIAC film production Analisi del lavoro ("analysis of work") (dir. Ansano Giannarelli, 1971). This very short film opens with a quotation from Marx and uses film sequences realized after having clandestinely accessed a factory so as to document and explicitly discuss working-class alienation.

It is in this context that Elio Petri directed the film which may be considered as the most significant and perhaps the first Italian fiction entirely focused on the working class and on the factory as working environment: Lulu the Tool (La classe operaia va in Paradiso ["the working class goes to heaven"], 1971). ${ }^{31}$ All the elements that I have retraced in the films

30 Corbella, "Sperimentazione elettroacustica e cinema d'autore," 99-100.

31 Evan Calder Williams, "The Fog of Class War: Elio Petri's The Working

Class Goes to Heaven, Four Decades On," Film Quarterly 66, no. 4 (2013), 50-9. 
discussed so far are present in this film and developed at a high level of cinematic self-awareness. To achieve this goal, Petri could count on scriptwriter Ugo Pirro, leading actor Gian Maria Volonté, and composer Ennio Morricone.

The film was shot at the Falconi factory, an elevator manufacturer in Novara, Piedmont. Petri received permission to use this location as the film's set only because the corporation had gone bankrupt and was under temporary receivership. Significantly, the factory was also in some way occupied by the workers at the time of the shooting. Petri was moved to hire the dismissed workers as extras so as to give them some financial support in that difficult moment. But there is no attempt at documentation in this film, except that the facts depicted in it were inspired by events that had occurred earlier in Rome. The fictional construction of the film relies on two main aspects: the absolute focus on the worker Ludovico Massa, aka Lulù (Volonté), and the presence of music as a main character.

The film subject encouraged Morricone to work creatively so as to express aspects of the relationship between the worker's body and the machine in the context of piecework production. The sound of the power press, which stands for piecework production in general, is integrated within the score in the form of an imitation realized through the Synket, with the addition of palm-muted electric guitar effects. ${ }^{32}$ This is the first sound heard in the film (over the head titles). The opening, rhythmically irregular bursts of sound, as if dictated by a working process or by the ignition of the machine, alternates with heavy staccato minor chords in the strings and piano. The latter gradually establish a regular pulse which soon becomes obsessive. The voice of the workers, as Morricone indicates, is represented by the rough entrance of the trombones to which the "intestinal" sounds of the contrabassoon in the lower register are added (Example 4). ${ }^{33}$

Traditionally, trombones in music stand for hell. It is clear that the factory, in the context of the film's original title which includes the word "paradise," is depicted as a kind of hell. ${ }^{34}$

32 Ennio Morricone and Alessandro De Rosa, Inseguendo quel suono: La mia musica, la mia vita (Milan: Mondadori, 2016), 101-2. The Synket was a protosynthesizer produced by inventor Paolo Ketoff in 1964 and later developed with further customizations. See Maurizio Corbella, "Paolo Ketoff e le radic cinematografiche della musica elettronica romana," AAA-TAC 6 (2009), 65 75. See also Luigi Pizzaleo, Il liutaio elettronico e l'invenzione del Synket (Rome: Aracne, 2014)

33 Morricone and De Rosa, Inseguendo quel suono, 101-2.

34 The idea that factory work is a kind of hell is a topos of early Soviet

cinema. In this respect Pudovkin's film The End of St. Petersburg (Konets Sankt-

Peterburga, 1927) is a relevant example. See David C. Gillespie, Early Soviet
Obsessive minor chords together with trombones and other brass and woodwind instruments were already present in a sequence in the industrial film Centrale elettronucleare del Garigliano: Una nuova fonte di energia ("Garigliano electronuclear power station: a new energy source"; dir. Daniele G. Luisi, 1964), scored by Morricone. This confirms the extent to which composers' experience with the industrial film shaped their work and imagination in those years.

In contrast to this industrial film, in Lulu the Tool the workers are seen as dehumanized by the frantic working pace imposed by industrial production. Metaphorically, they are half-animals ("it is a work that even monkeys could do," says Lulù to his apprentices) and half-machines. Near the beginning of the film Lulù, early in the morning, compares the human body to the factory: an organism including an operative center (the brain), and an internal production (digestive system) that takes the raw material (food) and crushes it so as to transform it into the end-product (excrement). This is the subject of Lulù's dialogue with his partner Lidia (Mariangela Melato), or, rather, a monologue in front of her and her son Arturo. When the camera frames Arturo's toy spaceman helmet, the Synket is heard, thus invoking the sci-fi topos while at the same time marking the passage to images of Lulù and the crowd of workers entering the B.A.N. factory (again an acronym and another stand-in for FIAT).

The episode is anything but innocent. The chaotic environment is the result of social struggles and the fragmentary political landscape that emerged from the Left after 1968. The emissaries of trade unions of different political persuasions are on one side, and student movements including extraparliamentary activists stand on the other. The latter use loudspeakers to declare their stances and invite the workers to strike against the company and particularly against piecework production (which they propose to abolish). This intentionally establishes a chaotic soundscape, which is almost unbearable for the viewers. Here we find an expansion of the music of the titles, which now alternates with a violin solo cadence. The cadence reaches beyond the trite romantic convention it exemplifies. ${ }^{35}$ Rather, it is the musical topos of the expressive, albeit neglected, human essence (in Marx's terms) of the workers. Its first appearance is synchronized with the image of

Cinema: Innovation, Ideology and Propaganda (London/New York: Wallflower Press, 2000), 63.

35 For details on Morricone's score and orchestration, see Sergio Miceli, Morricone, la musica, il cinema (Milano: Ricordi/Modena: Mucchi, 1994), 249 50. 


\section{Example 4: Lulu the Tool (dir. Elio Petri, 1971): transcription of Ennio Morricone's trombone theme as heard in the film's opening titles and during the entrance of the workers in the factory}
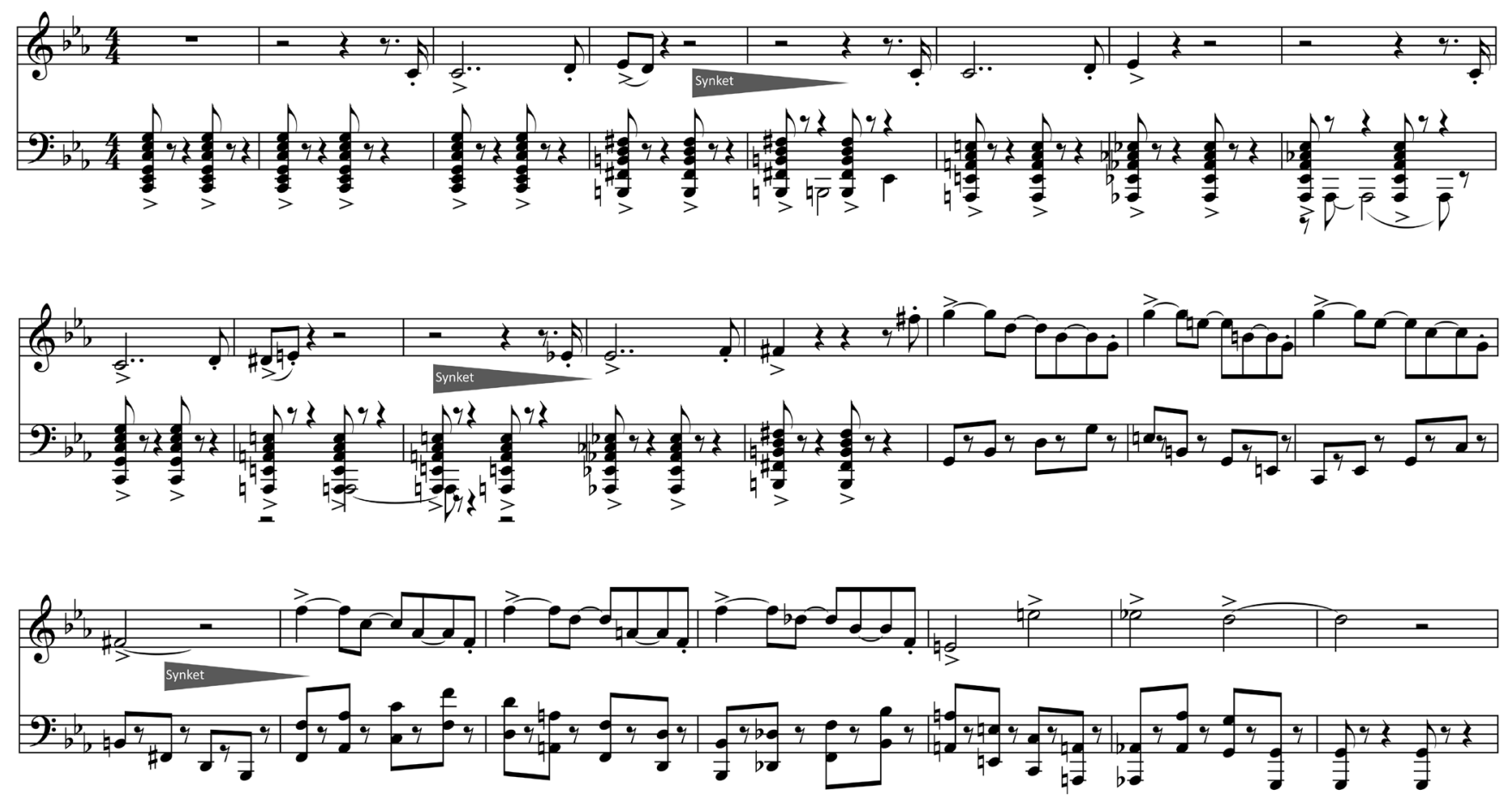

two students (one of them called Marx because of his beard and strong social commitment to the cause) shouting slogans into the loudspeakers so as to invite the workers to strike and take back their lives instead of accepting what the students call "forced labor." In the factory, the violin cadence is synchronized with shots of Lulù at the milling machine just before starting his work (Figure 9): the last oasis of humanity before the obsessive piecework production begins once again. ${ }^{36}$

The movements of Lulù working at the milling machine are synchronized with a musical process involving a three-note motif, explored in all its possible permutations. The piercing timbre of the wind instruments in the high register, together with the obsessive rhythm, here underlined by the drum, prefigures alienation as a step towards neurosis and even madness.

36 Morricone and De Rosa, Inseguendo quel suono, 101-2. In a different context, popular music is used, instead, to "mask" the "alienating soundscape of the factory." See Marek Korczynski, Songs of the Factory: Pop Music, Culture, and Resistance (Ithaca, NY/London: ILR [Cornell University Press], 2014), 190-1. Instead, Morricone's music aims to “unmask" alienation.
Another aspect of the working environment underlined in the film is the pervasive presence of health problems among the workers, especially sexual health problems. Aged 31, Lulù has already been poisoned twice from breathing the fumes of paint. He suffers from a gastric ulcer and impotence. Work absorbs all of his physical and psychological energies during the day. His own relationship with the machine is represented by Petri as a kind of sexual intercourse or a surrogate thereof. An identification between the machine and a traditional image of the woman as a person to be taken care of and treated gently in order to achieve certain results is part of the message the loudspeakers repeat every morning as soon as the workers take their place at the working station. The representation of Lulù's work at the milling machine is realistic: what might seem to be an excessive use of lubricants corresponds, instead, to the actual working experience. It may seem excessive only by comparison with its attenuated representation in corporate industrial films, as the latter are ideologically oriented towards concealing the more unpleasant aspects of the working environment. These shooting techniques 
Figure 9: Lulu the Tool (dir. Elio Petri, 1971): images synchronized with Ennio Morricone's violin cadence: a) the students at the gate; b) Lulù just before the beginning of work
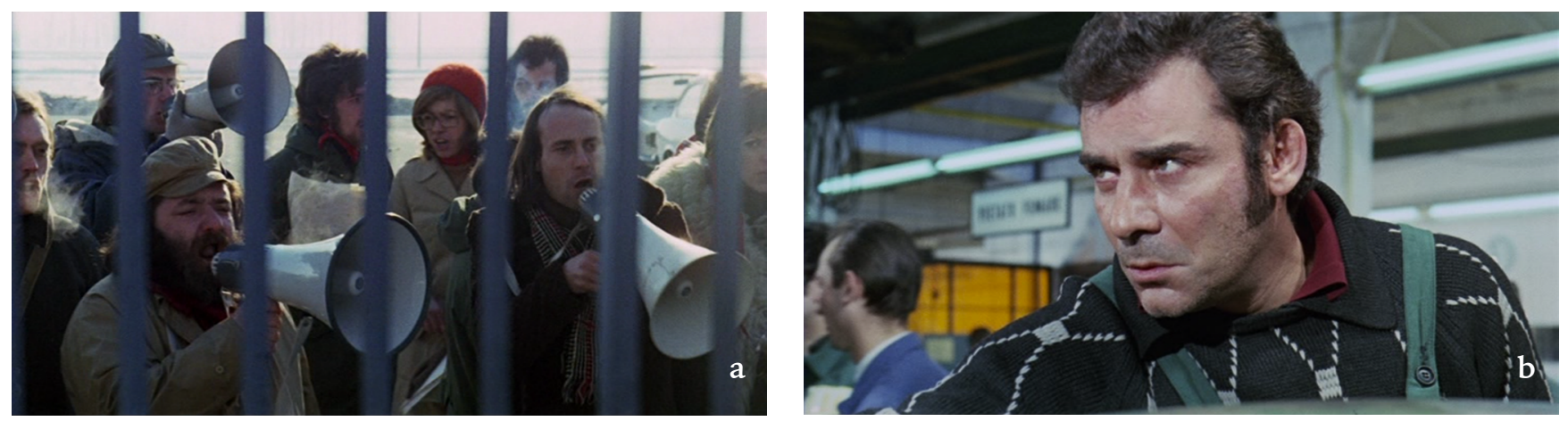

Example 5: Lulu the Tool (dir. Elio Petri, 1971): transcription of Morricone's dissonant chords in the melodica for neurosis and madness as heard in the film

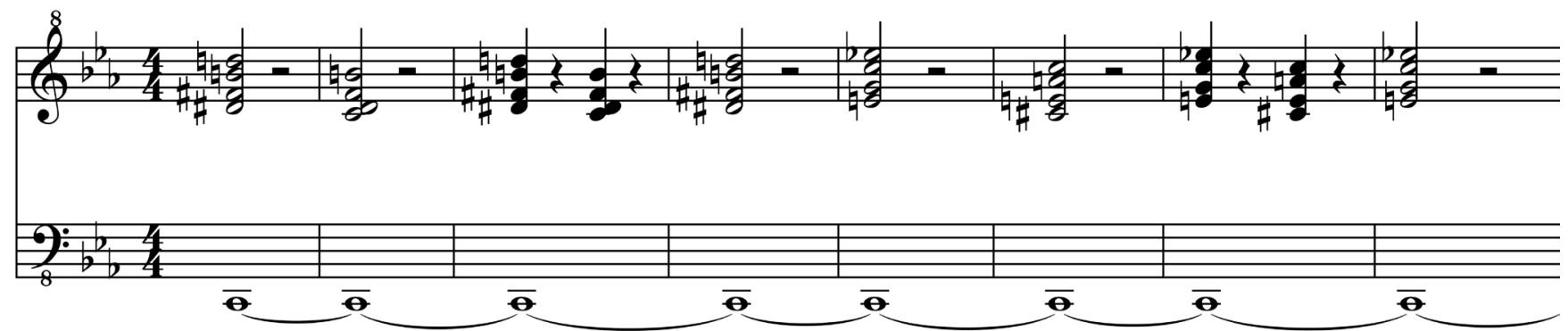

recall, not coincidentally, those used in pornographic films. While closely observed shots offer the most disturbing evidence of the working environment, the music does the same by sonically conveying the unpleasant aspects of work by means of timbres meant to disturb, even "harass" the listeners' ears.

Lulù explains to his apprentices that he is able to work fast by sending himself into a trance by "fixating" on an all-too-obvious part of the body of Adalgisa, a girl who works in the factory. Nothing else can be done in the factory, he says, except working and thinking about sex (posters with naked women are regularly removed from the work stations by the foremen). As he cuts industrial pipes into steel rings, every piece, in his vision, corresponds to a "hole," hence the following association: "one piece, one ass," as Lulù obsessively repeats to himself while working hastily at the milling machine (the image recalls, in a couple of short sequences, the fast motion of Omicron).

Lulù's Stakhanovite phase enters a crisis following the verbal attacks he receives daily from his co-workers. He gets angry, loses concentration and displays extreme behavior. His prevailing neurosis, close to madness, is musically represented by a fluctuating harmonic field within a rarefied soundscape characterized by a $\mathrm{C}$ drone in the low register, to which Morricone added electric guitar effects with heavy distortion and a tranquil, rocking pattern of dissonant chords in the high register of the melodica (Example 5).

This music appears just before the milling machine gets stuck on a piece, and Lulù imprudently tries to unblock it with his hand, eventually cutting off one finger-a metaphor for castration. Petri shows the blood interspersed with the lubricants and in the gears of the machine, thus offering another disturbing facet of the reality of factory work. The shocking event is shot out of focus, while the music at this point stops. Lulù's scream overrides the industrial noise of the factory's soundscape (Figure 10). ${ }^{37}$

After this accident, and partially as a consequence of the support he receives from workers from both sides of the political struggle-the labor unions on the one hand, the students' movement on the other-Lulù seems to acquire class consciousness. Yet, he also

37 The scream of the injured worker overwhelming the deafening sound of the looms in Mario Monicelli's The Organizer (I compagni, 1963) can be identified as a direct source for Petri. 
Figure 10: Lulu the Tool (dir. Elio Petri, 1971): a) Lulù on the edge of a nervous breakdown before the accident; $b$ ) Lulù's scream after the accident

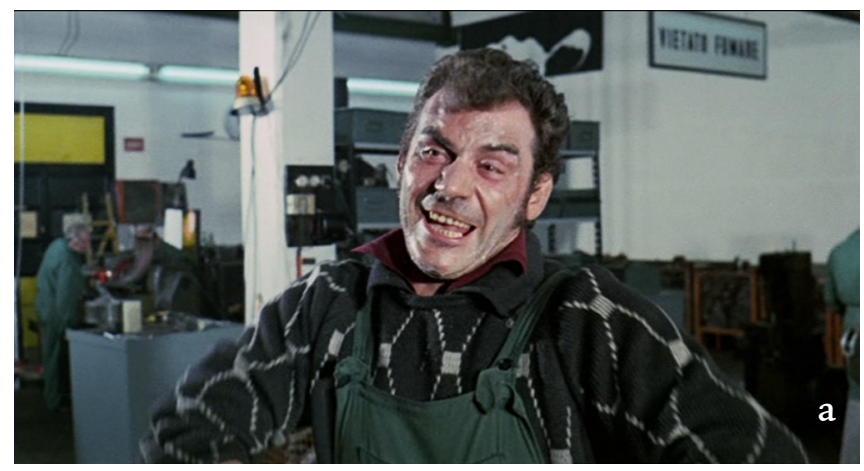

becomes disoriented. His attraction to Stakhanovism is replaced by other attractions that prove to be in the end no less disappointing. The students are too detached from working-class life, and their abstract, theoretical claims make no sense to Lulù. The labor unions are able to get Lulù his job back in the factory-having been fired in the meantime for becoming a protester-but he does not cry victory. His conversations in a mental hospital with Militina, a former worker who was driven insane by piecework production at B.A.N., convince Lulù that returning to the factory will condemn him to madness.

The last sequence in the film reveals Petri's deepest intentions as channeled by Morricone's music. Lulù has just been hired again by B.A.N. As a "lesson," the protesters among the workers have been assigned to the assembly line. This is not a "real" assembly line, but rather the symbol of an even more dehumanizing mode of production. Now it is the very system that dictates the speed of production, thereby pre-empting the need for intimidation by the foremen. The noises of the factory are accentuated, so much so that the workers are unable to understand each other. It is in this framework that Lulù narrates a dream aloud (yet barely heard by his colleagues due to the surrounding noise). The dream elaborates on the behavior of Militina, who in the mental hospital pressed his hands on a wall and imagined demolishing it. In the convoluted logic of the dream, Lulù recounts that he has seen himself dead, ready to go to heaven, but has been prevented from reaching it by an insurmountable wall. Therefore, he and the others have decided to demolish the wall and enter Paradise. But once in heaven there was only fog, and smoke rising from the wall now in ruins. Gradually, amidst this fog and smoke, Lulù has recognized Militina and the workers with whom he is working. He has recognized himself as well, identified as "a fingerless loser." It is clear that

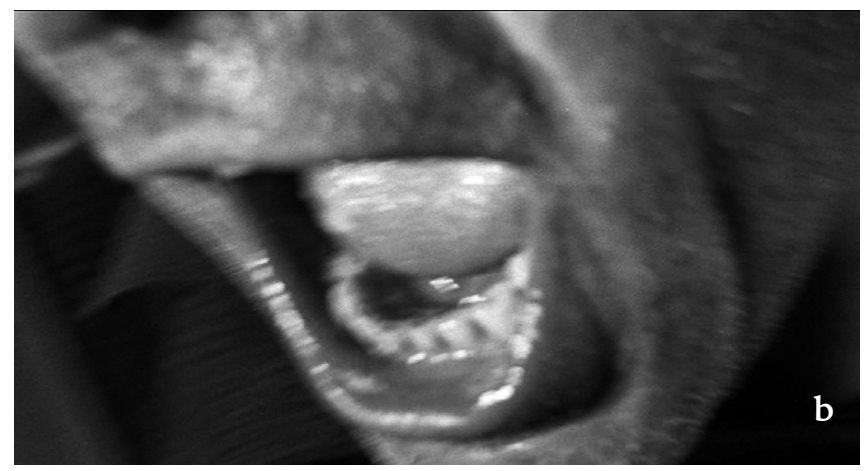

Paradise is nothing other than the factory itself, from which there is no escape (in this respect Petri's film responds to Red Desert from the point of view of the workers).

The workers refer what they manage to hear of Lulù's dream to each other, but not without twisting the words and their meaning. Then each of them asks about their own presence in heaven, and finally demands an explanation that Lulù is unable to give - to the extent that in the end he is overcome by boredom and denies both their presence and his own. The soundtrack-along with the fact that, unlike the workers we hear Lulu's voice quite clearly-suggests that we are sharing Lulù's perspective. We hear again the same tragic music heard in the scene of Militina in the psychiatric hospital (itself a variant of Example 5). The dream and its premonition is no more than an illusion. As the music certifies, the paradise promised by Lulù is a by-product of madness induced by factory work.

\section{Point of no Return}

The history I have thus far traced of the industrial soundscape as film soundscape ends, in a way, with Petri's film, and does so for numerous reasons. First, the industrial film as a genre of corporate communication had almost disappeared by the mid1970s, eroded on the one hand by the economic recession which got worse after the first oil crisis in October 1973 and, on the other, by the new communication strategies embraced by corporations, based on spot television advertising rather than on documentary films. Television demanded rapidity and a strict focus on the end-product, which implied a renunciation of informing about production processes, scientific research, or the social goals of industrial 
enterprise. In this respect the Carosello ${ }^{38}$ jingle coming from the TV set together with a pale blue light reverberating on Lulù's face in the initial sequence of Lulu the Tool is more than a premonition. The jingle is sung by a madman in the insane asylum, thus making television a cause of alienation alongside the factory.

Second, Petri's film, notwithstanding its unexpected box-office success, itself represented a point of no return. The unfavorable reception among many political facets of left-wing Italian parties, institutions, and movements (the Italian Communist Party, the trade unions, the students' movement) - let alone the government and the right-wing partiesresulted in a substantial ostracism. For the film tackled an all-too-prominent burning political agenda. This explains why Lulu the Tool was, in fact, the last film Petri was able to release with an effective distribution.

This connects to a third reason: during the 1970s class struggle as an armed struggle relying on the active role of the working class was the part of the extreme agenda of left-wing terrorist organizations, including the Brigate Rosse. This may have put any attempt to critically engage with the factory as working environment in a bad light, especially from the Marxist perspective that had been generally adopted by Italian cinema thus far. It is possible that before Lulu the Tool was even one year old, class struggle had become too closely enmeshed with public discourse about terrorists for the working class and the factory environment to remain an attractive subject for film directors to tackle directly. ${ }^{39}$

From a film music perspective, a fourth reason can be added: the idea of film music as conceived in the 1950s - that is, the work of an individual composer who is responsible for all the music as a main component of the film soundscape-had been gradually corroded by competition from popular music in the Italian film production practice during the $1960 s .{ }^{40}$ Morricone was one of the most active arrangers and composers in the popular music record industry and from the beginning of his activity as film composer he was involved in film productions characterized by the presence of both songs and orchestral score. Morricone's score for Petri's film explores the boundaries with popular music as well as with experimental music (electric guitars and drums expand the sonic range of the orchestra on the popular side as the Synket does on the experimental side), but "art" music is the milieu to which it ultimately refers. In so doing, Morricone positioned himself above musical genres in order to use and combine them, just as Petri did with film genres.

The composer's commitment as inventor of a consistent soundscape for an individual film is also a consequence of his political commitment, lying at the core of his collaboration with Petri. To take the industrial soundscape seriously implies, in fact, to engage both psychologically and politically with the factory as a scene of social injustice and struggle. Morricone's cameo as a factory worker at the end of Lulu the Tool is perhaps a visible metaphor of this engagement, shared by the leading actor Volonté. This can also go some way in explaining why the putative heirs of Petri's socially explosive film do not stand up to comparison with their supposed model. Attempts to deal with the working class in comedy, or in mixing romance and drama, ${ }^{41}$ reduced the factory to mere background scenery, also in sonic terms, for the film genre, including sonic and musical conventions, prevailed over the individual film.

What is evident, however, is that, well into the 1970s, the changing historical, economical, political, and media framework wiped out the cultural and production conditions that during the long 1960s had allowed film directors and composers to creatively and critically engage with the industrial soundscape.
38 Broadcast daily on RAI from 1957 to 1977 Carosello was a ten-minute Italian television programme consisting of short commercial messages. 39 The complete lack of references to the factory as working environment and to the working class in Italian films of the 1970s involving right- and left-wing terrorism confirms that while terrorism was one of the main subjects in many film productions, the factory and the working class became "unrepresentable," in terms of a political taboo. See Christian Uva, ed., Schermi di piombo: Il terrorismo nel cinema italiano (Soveria Mannelli: Rubbettino, 2007).
40 See Alessandro Bratus's article in the present issue.

41 I refer to such films as The Seduction of Mimi (Mimi metallurgico ferito nell'onore; dir. Lina Wertmüller, 1972) and Il sindacalista ("the trade

unionist") (dir. Luciano Salce, 1972) on the one hand, and, on the other, to Delitto d'amore ("crime of love") (dir. Luigi Comencini, 1974). 


\section{References}

Bellotto, Adriano. 1994. La memoria del futuro: Film d'arte, film e video industriali Olivetti 1949-1992. Rome: Fondazione Adriano Olivetti.

Calabretto, Roberto. 2010. Lo schermo sonoro: La musica per film. Venice: Marsilio.

___. 2012. Antonioni e la musica. Venice: Marsilio.

Carocci, Giovanni. 1958. Inchiesta alla FIAT. Nuovi argomenti 31-32.

_——. 1960. Inchiesta alla FIAT. Florence: Tipografia Parenti.

Cecchi, Alessandro. 2013 Topoi of technology in Italian 'experimental' industrial film (1959-1973). In Proceedings of the International Conference on Music Semiotics in Memory of Raymond Monelle (University of Edinburgh, 26-28 October 2012), 394-403, ed. N. Panos et al. Edinburgh: IPMDS. http://sites.ace.ed. ac.uk/edmusemiotics/proceedings

- _ - 2014. Creative titles: Audiovisual experimentation and self-reflexivity in Italian industrial films of the economic miracle and after. Music, Sound, and the Moving Image 8, no. 2: 179-94.

Cecchi, Alessandro, and Maurizio Corbella. 2012. Experimentation, documentation, censorship: A Joris Ivens's industrial film and the Italian national broadcasting television. Paper delivered at Music and Media 4th IMS Study Group Meeting, Turin, June 28-29, 2012.

Chayt, Eliot. 2015. Revisiting Italian post-neorealist science-fiction cinema (1963-74). Science Fiction Studies 42, no. 2: 322-38.

Comuzio, Ermanno. 1994. Piccioni specchio di Sordi, ovvero: Sembra facile, quella musica ... In L'immagine e il suono: Alberto Sordi-Piero Piccioni. Seminario di studio e premio "Il Trefolo d'oro" Università per Stranieri di Siena, 9-26, ed. S. Micheli. Siena: Il leccio.

Corbella, Maurizio. 2009. Paolo Ketoff e le radici cinematografiche della musica elettronica romana, $A A A-$ TAC 6: 65-75.

_——. 2011. Sperimentazione elettroacustica e cinema d'autore in Italia negli anni Sessanta: Due casi di studio. Comunicazioni Sociali 1: 93-101.

Dagrada, Elena. 2005. Le varianti trasparenti: I film con Ingrid Bergman di Roberto Rossellini. Milano: LED.

During, Lisabeth. 2016. Saints, scandals, and the politics of love: Simone Weil, Ingrid Bergman, Roberto Rossellini. Substance 45, no. 3: 16-32.

Falchero, Anna Maria. 2008. Cinema e industria: I documentari industriali. Storia-Politica-Società 41, nos. 3-4: 129-42.

Gillespie, David C. 2000. Early Soviet cinema: Innovation, ideology and propaganda. London/New York: Wallflower Press.

Ginsborg, Paul. 1990. A history of contemporary Italy: Society and politics 1943-1988. London: Penguin Books.

Halfyard, Janet K. 2010. Mischief afoot: Supernatural horror-comedies and the diabolus in musica. In Music in the horror film: Listening to fear, 21-37, ed. N. Lerner. New York/London: Routledge.

Korczynski, Marek. 2014. Songs of the factory: Pop music, culture, and resistance. Ithaca, NY/London: ILR (Cornell University Press).

(C) The International Film Music Society 2019.

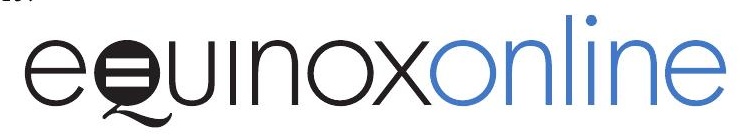


Latini, Giulio. 2011. L'energia e lo sguardo: Il cinema dell'Eni e i documentari di Gilbert Bovay. Rome: Donzelli.

Mera, Miguel. 2002. Is funny music funny? Contexts and case studies of film music humor. Journal of Popular Music Studies 14, no. 2: 91-113.

Miceli, Sergio. 1994. Morricone, la musica, il cinema. Milan: Ricordi/Modena: Mucchi.

Morricone, Ennio, and Alessandro De Rosa. 2016. Inseguendo quel suono: La mia musica, la mia vita. Milan: Mondadori.

Mosconi, Elena. 1991. Il film industriale. Comunicazioni Sociali 13, nos. 1-2: 61-90.

Mosconi, Elena, and Luigi Boledi. 1996. Il film industriale. In Un secolo di cinema a Milano, 295-311, ed. R. De Berti. Milan: Il Castoro.

Pizzaleo, Luigi. 2014. Il liutaio elettronico e l'invenzione del Synket. Rome: Aracne.

Rosar, William R. 2006. Music for Martians: Schillinger's two tonics and harmony of fourths in Leith Steven's score for War of the Worlds (1953). Journal of Film Music 1, no. 4 ("Leith Amadeus Stevens: A Festschrift"), 395-438.

Rothermel, Dennis. 2014. Workerist film humour. In Marx at the movies: Revisiting history, theory and practice, 123-46, ed. E. Mazierska and L. Kristensen. Basingstoke: Palgrave Macmillan.

Tagg, Philip. 1998. Tritonal crime and 'music as music'. In Norme con ironie: Scritti per i settant'anni di Ennio Morricone, 273-312, ed. S. Miceli. Milan: Suvini Zerboni. http://tagg.org/articles/xpdfs/morric70.pdf (accessed October 2016).

Tillman, Joakim. 2017. Topoi and intertextuality: Narrative function in Hans Zimmer's and Lisa Gerrard's music to Gladiator. In Music in epic film: Listening to spectacle, 59-85, ed. S.C. Meyer. New York/ London: Routledge.

Uva, Christian, ed. 2007. Schermi di piombo: Il terrorismo nel cinema italiano. Soveria Mannelli: Rubbettino.

Verdone, Mario. 1960. Note. L'Italia non è un paese povero. Bianco e Nero 21, no. 7: 87-90.

Williams, Evan Calder. 2013. The fog of class war: Elio Petri's The Working Class Goes to Heaven, four decades on. Film Quarterly 66, no. 4: 50-9.

Wierzbicki, James. 2005. Louis and Bebe Barron's Forbidden Planet: A film score guide. Lanham, MD: Scarecrow Press. 